\title{
Groundwater Contribution to Surface Water Contamination in a North German Low Land Catchment with Intensive Agricultural Land Use
}

\author{
Muhammad Waseem*, Tatyana Koegst, Jens Tränckner \\ Faculty of Agriculture and Environmental Sciences, Universität Rostock, Rostock, Germany \\ Email: *muhammad.waseem@uni-rostock.de
}

How to cite this paper: Waseem, M., Koegst, T. and Tränckner, J. (2018) Groundwater Contribution to Surface Water Contamination in a North German Low Land Catchment with Intensive Agricultural Land Use. Journal of Water Resource and Protection, 10, 231-250.

https://doi.org/10.4236/jwarp.2018.103014

Received: December 17, 2017

Accepted: March 11, 2018

Published: March 14, 2018

Copyright $\odot 2018$ by authors and Scientific Research Publishing Inc. This work is licensed under the Creative Commons Attribution International License (CC BY 4.0).

http://creativecommons.org/licenses/by/4.0/

\begin{abstract}
The contribution of groundwater (GW) to the nitrate loads in surface waters (SW) was exemplarily studied for the river Augraben with a catchment area of $89.9 \mathrm{~km}^{2}$, located in north eastern Germany. The study uses available GW and SW quality data in order to develop a relationship between SW and GW in the Augraben catchment. The calculated ratio of base flow varies from $40 \%$ to $80 \%$ using various filtering methods of hydrograph separation methods (without taking into account the drainage) in comparison to a calculated GW infiltration of 5\% - 7\% applying Darcy's law (upper unconfined aquifer). Drainage was estimated as the difference in base flow obtained through filtering methods of hydrograph separation and the Darcy's law. Results on the basis of monitoring data and hydrograph separation in quick flow and base flow showed that during winter periods, high concentration in SW has been found parallel to periods of higher GW flow with a strong correlation between SW and GW concentrations. These findings also coincided with the non-vegetation period, i.e. low nitrogen uptake by plants. Overall, nitrate-nitrogen loads at the SW monitoring point (Bei Lindenberg represents the $85 \%$ area of the catchment) were 193.5, 97.72, and 122 tons for the year 2010, 2011 and 2012 respectively. Measured GW concentrations in the catchment differ strongly, depending on land use, with elevated concentrations in agricultural areas compared to monitoring points in grass land and in forest areas. In one GW monitoring station, $\mathrm{NO}_{3}$ concentrations exceed the maximum permissible limits (MPL) according to $\mathrm{EU}$ water quality standards (MPL $=50 \mathrm{mg} / \mathrm{l} \mathrm{NO} \mathrm{N}_{3}$ ), up to factor two. High ammonia concentrations at another station may be due to excessive application of manure. The contribution of the different sub-catchments to nitrate load in SW can be ranked in decreasing order in Zone B, D, A and C. Drainage and interflow proved to be a major contributor with $55 \%-65 \%$ of total
\end{abstract}


load in SW. With the applied method a robust estimation of GW contribution to nitrate loads is feasible using typically available monitoring data of German environmental authorities.

\section{Keywords}

Base Flow Separation, Diffuse pollution, Drainage and Interflow, Groundwater Nitrogen, Gehmkow Augraben

\section{Introduction}

Agriculture related pollution has attracted increased attention worldwide over the past 40 years due to its important consequences on water quality [1] [2]. Nitrogen inputs in intensive-agricultural catchments have been identified as the major causal factors in the trends of increased nutrient concentrations in surface, ground and coastal waters [3], though inputs from effluents and atmospheric deposition are also important. Nitrate is the most frequently introduced pollutant into GW systems [4]. Pollution of GW and SW by diffuse sources is a serious problem in the EU [5]. Use of fertilizer for agricultural production enhancement continues to negatively affect the overall water quality in Germany and especially the GW [6]. Nitrate in GW can origin from direct application in mineral fertilizer or via the transformation from ammonia, either from mineral fertilizers or manure from animal husbandry. Though Ammonia is as cation in tendency better retained in soil, its ecotoxic relevance is even higher due to the high oxygen demand when transformed to nitrate and the acute toxicity of $\mathrm{NH}_{3}$ [7] [8]. Due to its main input source, ammonia toxicity in aquatic systems is of special concern in regions of high human habitation and deficient wastewater treatment and/or large numbers of farm animals [9]. As causal chain, nitrogen losses from the upper soil are generally increasing nitrate concentration in GW and its discharge towards the SW system may cause exceedance of SW quality standards as well [10] [11] [12].

Maximum acceptable concentration of nitrate for potable water according to the World Health Organization (WHO) is $11.3 \mathrm{mg} / \mathrm{l} \mathrm{NO}_{3}-\mathrm{N}$ or $50 \mathrm{mg} / \mathrm{l} \mathrm{NO}_{3}$ [13]. The same concentration is defined as threshold for good chemical status of GW according to the European Water Framework Directive. But also below this threshold, nitrate is highly relevant because of its eutrophication potential. In 2010 the total nitrogen input in Baltic Sea through water and airborne sources was 977,000 tons of nitrogen. Manure leaching accounts for $60 \%-70 \%$ of the total diffuse and more than half of the waterborne inputs in the Baltic Sea [14].

Accordingly, pollution of GW and SW through diffuse sources is a major concern in federal State of Mecklenburg-Vorpommern (MV) in north-eastern Germany and ultimately in the Baltic Sea. Objectives to reduce eutrophication are set in Baltic Sea Action Plan (BSAP), implemented in 2007 [15] and reviewed in 2013 [16]. In 5th Baltic Sea pollution load compilation (PLC5.5) a 9\% reduction 
in total nitrogen loads in Baltic Sea was estimated from period between 1997 to 2003, but it is also observed that a further reduction of $14 \%$ is still required [17]. Analyzing trends in monitoring data from 1970 to 2000, Saaltink et al. [18] found that the reduced loads in nitrogen is not evenly distributed but display large spatial variation and are related to the socio-economic developments within the Baltic Sea Basin. The estimated required abatement similarly varies significantly with a required reduction of up to $26 \%$ in the Baltic Sea [17] of which $5000 \mathrm{t} / \mathrm{a} \mathrm{N}$ shall be reduced by the state MV. Specific estuaries and coastal waters may require even higher specific abatements in order to protect coastal and transitional water ecosystems and comply with the good status objectives of the Water Framework Directive [19].

Nitrogen transport and reduction has been studied for the federal state of MV by Wendland et al. [20]. This study is comprised of a nutrient balance model, a water balance model (GROWA), a reactive nitrate transport model in soil (DENUZ) and a reactive nitrate transport model in GW (WEKU). Drainage was found to be a dominant pathway resulting in approximately $35 \%$ of the $\mathrm{N}$ transport leaching from the agriculture fields to the SW bodies. In federal state of $\mathrm{MV}$, it is estimated that $54 \%$ of the nitrogen leaving the root zone is reduced before it reaches the SW bodies due to denitrification [20]. Comparison with monitoring data shows that the model predicts actual loads for larger catchment areas better than for smaller ones. The calculated partitioning can so far hardly be proved.

In January 2017, Germany published its most recent report on nitrate pollution of waters ("Nitratbericht 2016", for the monitoring period up to and including 2014), in line with the obligations under the EU Nitrates Directive. The report underlines that agricultural fertilizers continue to negatively affect water quality in Germany, in particular GW. Almost one third of the monitoring points for GW quality show values above the limit value of $50 \mathrm{mg} / \mathrm{l}$ nitrate. In case of MV, recently a study carried out in Zarnow basin showed that $32 \%$ of all the GW samples exceeds the permissible drinking water threshold value of 11.3 $\mathrm{mg} / \mathrm{l} \mathrm{NO}_{3}-\mathrm{N}$ [21]. While another study carried out in $\mathrm{MV}$, states that $76 \%$ of the monitored SW have at least a significant pollution with nitrate and $40 \%$ with phosphate [22]. Different mediums like GW, drainage, surface runoff and atmospheric deposition etc., have their different shares in transport of nitrates into the SW. A study, carried out in MV and Schleswig-Holsteins about the role of different sources of diffuse emission in Baltic Sea shown in Figure 1, yielded that drainage (51\% of total load) and GW (39\% of total load) are the dominant pathways [23].

To protect the valuable GW resources, several approaches were developed to predict and estimate nitrate contamination from different sources. One approach is applying solute leaching models [13], which are difficult to calibrate and their boundary conditions cannot be easily satisfied in complex land use systems and non-uniform strata [24]. An easier and more convenient method is to make the comparison and integration of SW and GW quality data from monitoring 


\section{Phosphorus \%}

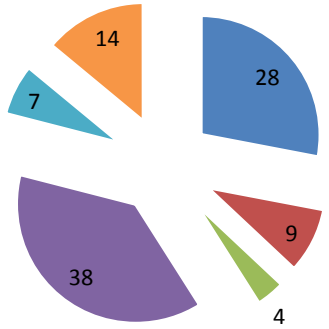

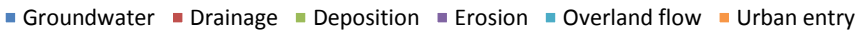

Nitrogen \%

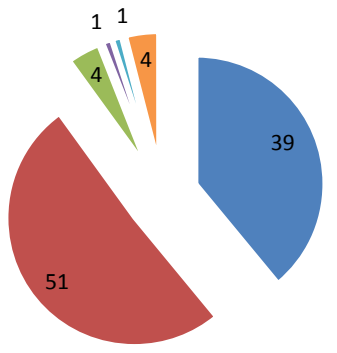

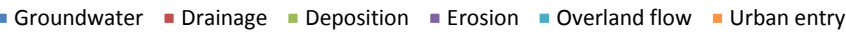

Figure 1. Pathways contributing to eutrophication of the Baltic Sea [23].

networks. Though these approaches do not describe the processes itself, they can combine available data with adapted conceptual approaches to get reliable estimates of the pathways.

In this study, GW flow in a characteristic lowland river, the Augraben, was estimated by using two different methods named as 1) Hydraulic gradient method/ Darcy's Law 2) hydrograph separation method. Hydraulic gradient method is based on aquifer characteristics and the measured hydraulic gradients in the river and nearby available borehole. This method works well in local GW fluxes near to the gauging stations. But it does not always represent good estimations of GW flow in longer reaches. Hydrograph separation method takes into account the time series record of river discharge and then separates it (in minimum) into base flow and quick flow [25]. Since separation methods are no process models, the interpretation of base flow and quick flow is often not distinct, especially with regard to interflow (e.g. drainage).

Objective of this study is to develop and apply a method to assess the contribution of GW to the nitrogen load in SW based on available authorial monitoring data. Focused on the case study, the following targets shall be reached: first, comparison of the SW and GW concentrations at the available GW and SW quality monitoring stations and quantification of critical nitrate, nitrite and ammonium loads during vegetation and non-vegetation periods in Augraben 
catchment; secondly, quantification of GW contribution to measured nitrogen load in the Augraben.

In order to get these objectives, available data are analyzed at each SW and GW quality monitoring station. Ultimately, a trend of SW and GW concentrations and estimation of nitrogen loads during different growing seasons is estimated. In order to find the GW inflow and its impact, total flow is divided into base flow and quick flow, with further distinction of base flow applying Darcy's law. Main focus of this study is on nitrogen compounds introduced by GW into the Augraben $\left(\mathrm{NO}_{3}-\mathrm{N}, \mathrm{NO}_{2}-\mathrm{N}, \mathrm{NH}_{4}-\mathrm{N}\right)$.

\section{Materials and Methods}

\subsection{Study Area}

Figure 2 shows the location of the outlet and catchment area of the Augraben in MV in the lowlands of north eastern Germany. Since the SW monitoring station

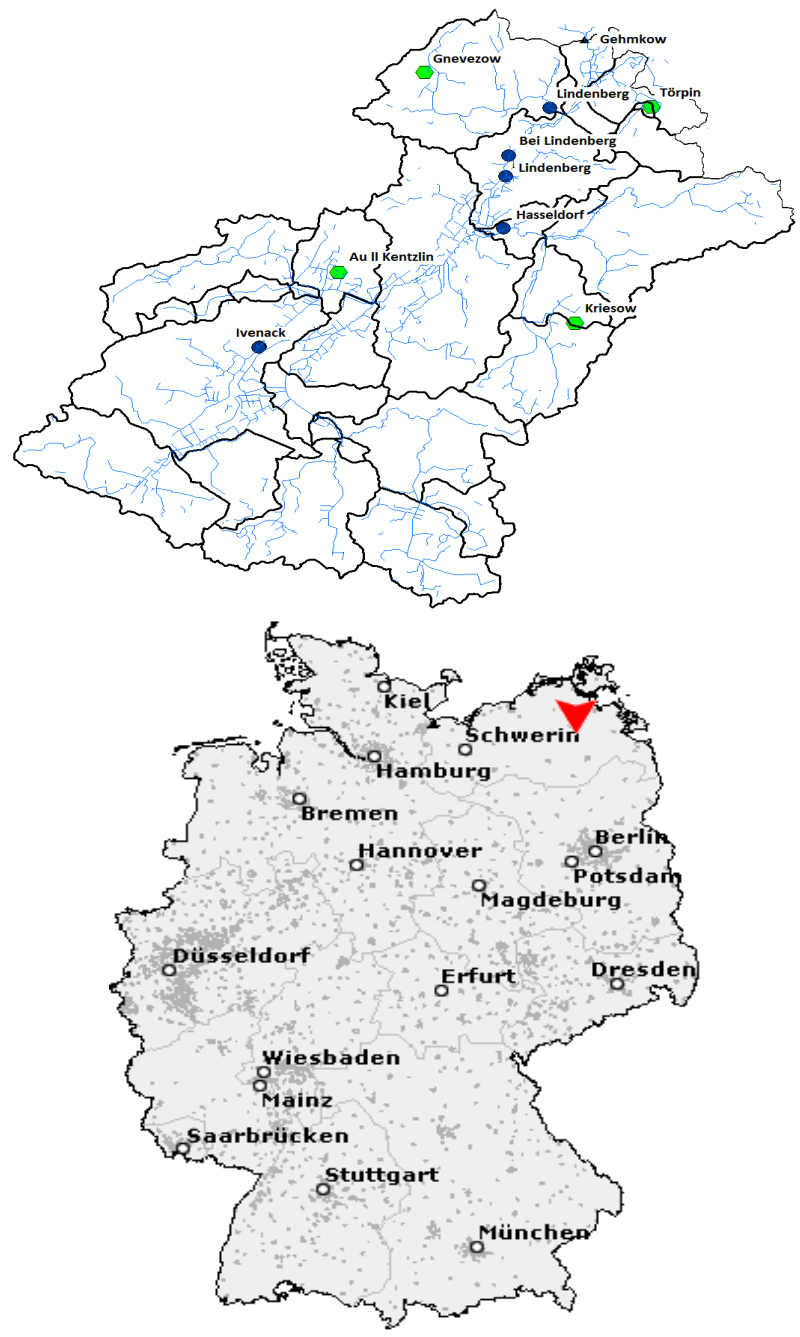

Figure 2. (Down) Location of Gehmkow in MV, Germany. (Up) Location of GW quality monitoring stations (Green), SW quality monitoring stations (dark blue) and small rivers (light blue) in the catchment area. 
is not located at the mouth into the river Tollense, but several kilometers upstream, the contributing catchment area is cut back accordingly and comprises $89.9 \mathrm{~km}^{2}$ shown in Figure 2. The actual land use was estimated by the aerospace images obtained from Rapid Eye Science Archive website [26]. Study area consist of $2.22 \%$ water, $2 \%$ settlements, $18 \%$ forest area, $75 \%$ arable and grassland while $3 \%$ miscellaneous. The catchment area is mainly used for agriculture and is equipped with artificial drainage. Tile drainage was established in the study area in 60 s and 70s. It was not possible to obtain the tile drainage maps of the farms due to data privacy protection.

\subsection{Estimation of GW Pollution with GIS}

GIS was used for the effective management of GW quality data [27] [28] [29] [30]. A database of the chemical constituents of GW and the spatial data layers using GIS version Arc Map 10.1 was constructed to investigate the spatial relationship between the GW constituents and pollution sources. Land use images were obtained from Rapid Eye images [26]. Spatial data which includes stream, road, contour, geologic, land use, and a pollution source map and attributed data was used, which include chemical constituents of sampling sites. Artificial drainage was constructed in Arc-GIS to get an idea of natural drainage system in the study area. A digital elevation model (DEM) was used to predict the surface flow based on the topography of the catchment. Plausible drainage areas were constructed based on the topography using Arc hydro tools in GIS (Figure 3). These could be different from the actual artificial drainage system installed in the study area but give a rough idea of main flow direction of small channels in the area under investigation.

\subsection{Data Acquisition and Processing}

\subsubsection{Water Quality Data}

1) $\mathrm{GW}$

Three out of total 25 available GW boreholes are in use by Landesamt für Umwelt, Naturschutz und Geologie Mecklenburg-Vorpommern (LUNG-MV) for GW quality monitoring on seasonal basis. Monitoring interval for the GW quality assessment is every 6 months. Table 1 shows the available GW quality data from the 2011 to 2014 for the available GW quality monitoring stations in the study area.

As there was no GW data available in zone $\mathrm{A}$ and $\mathrm{C}$, a measurement campaign was launched and GW quality data was collected on monthly basis at Gnevezow (Zone A) for a period of 6 months from January 2017 till June 2017. GW samples were collected and analyzed onsite for nitrate, nitrite and ammonia contents. While in case of zone $\mathrm{C}$, no boreholes were available in that area so GW concentrations in the nearest zone $\mathrm{B}$ were used. Reason behind this assumption was that the land use in zone $\mathrm{B}$ and zone $\mathrm{C}$ is similar having similar assumed fertilizer application rates. GW quality concentrations for all the available stations 


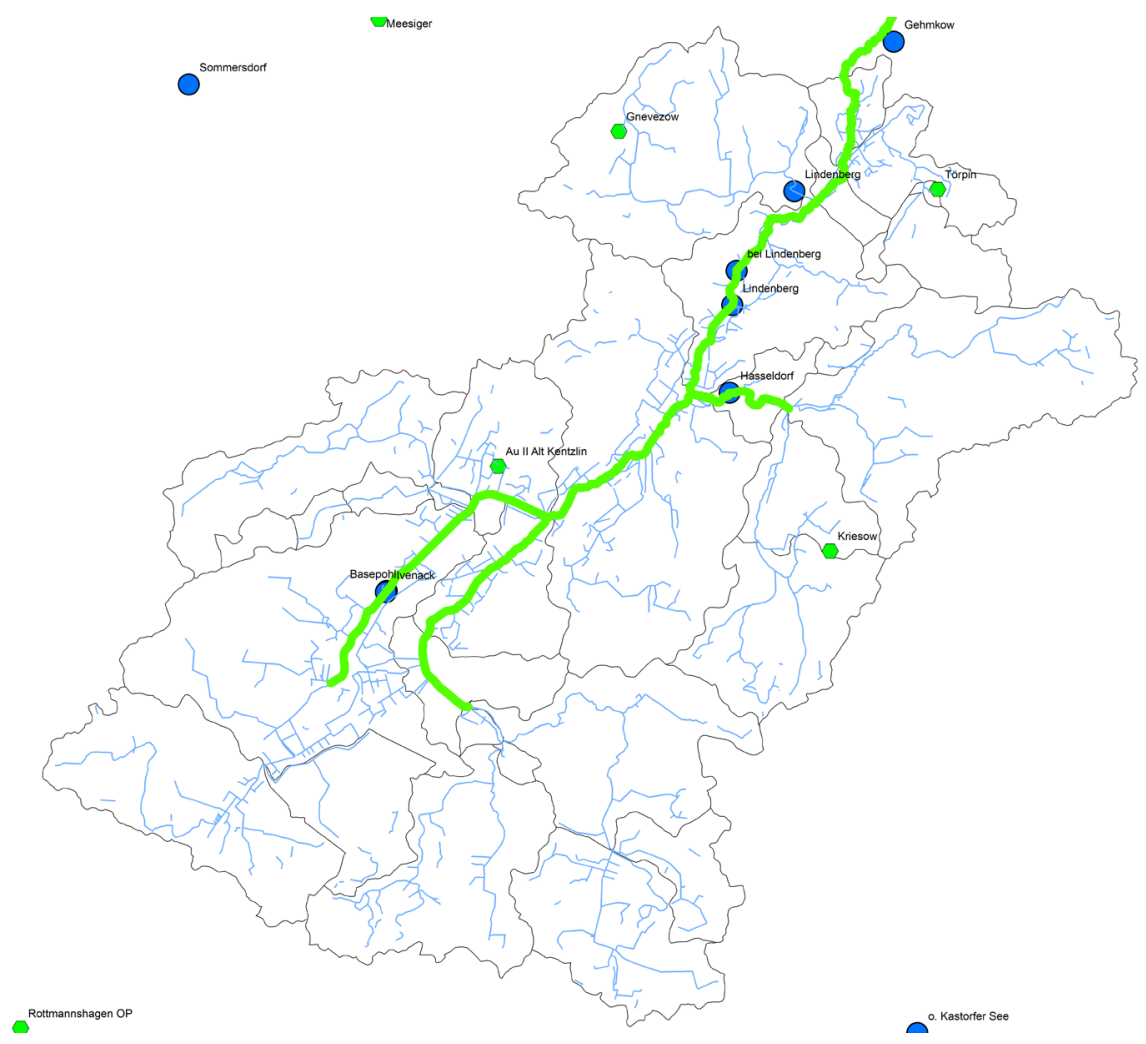

Figure 3. Artificial SW drainage constructed in Arc GIS (green lines) by using arc hydro tools.

Table 1. GW quality monitoring stations with sampling interval of 6 months.

\begin{tabular}{cccccccccc}
\hline Station Name & \multicolumn{2}{c}{2011} & \multicolumn{2}{c}{2012} & \multicolumn{2}{c}{2013} & \multicolumn{2}{c}{2014} & Sampling Interval \\
\hline Au II Kentzlin & ----- & Dec & April & Oct & April & Oct & April & Oct & \\
Törpin & Aug & Dec & April & Oct & April & Oct & April & Oct & 6 months \\
Kriesow & Aug & Dec & April & Oct & April & Oct & April & Oct & \\
\hline
\end{tabular}

were analyzed for $\mathrm{NO}_{3}-\mathrm{N}, \mathrm{NO}_{2}-\mathrm{N}$ and $\mathrm{NH}_{4}-\mathrm{N}$ concentrations and concentration trends have been established.

2) SW

SW quality monitoring in the study area is organized and managed as well by state authorities. SW quality data at a particular sub catchment outlet represents and characterize the integrated impact of that whole particular sub catchment. SW inflow into the Augraben was divided into four zones Lindenberg (yellow), Hasseldorf (Green), Grischow (light green) and Ivenack (grey) shown above in Figure 4.

SW quality data was collected and analyzed at each of the available SW quality assessment stations in order to identify the critical locations in terms of nitrate pollution and also to establish the trends how the nitrogen concentration changes during the years against the flow in these areas. Table 2 shows the SW quality data at available monitoring stations with their sampling intervals.

SW quality and discharge data were analyzed at the gauge station installed 


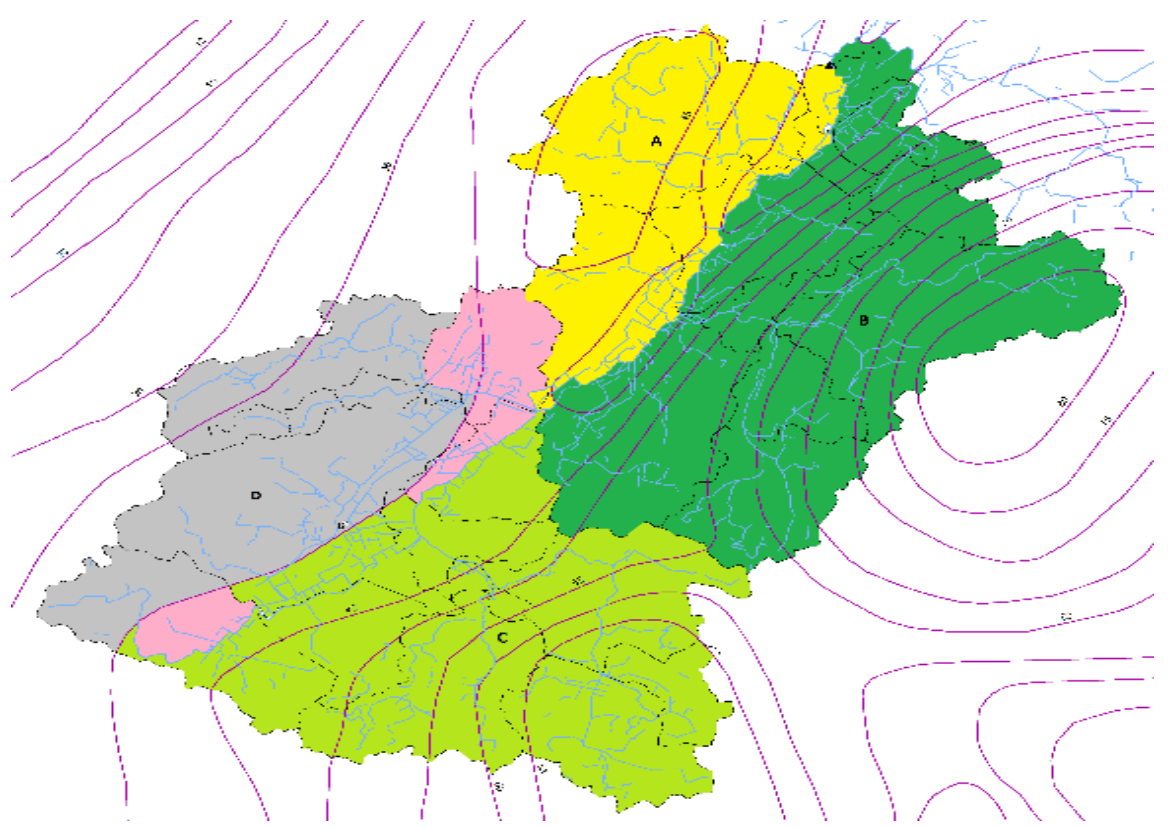

Figure 4. GW contribution in the Gehmkow Augraben divided in Zone A (yellow), B (green), C (light green) and D (grey).

Table 2. SW quality monitoring stations with monthly sampling interval.

\begin{tabular}{ccccccc}
\hline Station Name & 2011 & 2012 & 2013 & 2014 & 2015 & Sampling Interval \\
\hline Lindenberg & $\checkmark$ & $\checkmark$ & $\checkmark$ & & & Monthly \\
Hasseldorf & & $\checkmark$ & & & $\checkmark$ & Monthly \\
Ivenack & $\checkmark$ & & & $\checkmark$ & & Monthly \\
Bei Lindenberg & & & $\checkmark$ & $\checkmark$ & $\checkmark$ & Monthly \\
\hline
\end{tabular}

near Gehmkow, representing the outflow of almost $85 \%$ of the whole Augraben catchment. Flow at each outlet of four zones A, B, C and D was estimated from the average flows data provided by Biota shown in Figure 5, and the available flow data at the Gehmkow outlet shown in Figure 6. Hydrograph separation was done at Bei Lindenberg where maximum measured data was available and represents a large portion (almost $85 \%$ of the total catchment) in order to separate the flow into base flow and in quick flow conditions to know the impact of GW on Nitrogen load in the Augraben. GW flow was separated combining hydrograph separation and Darcy's law/Hydraulic gradient method to quantify the impact of GW on SW nitrate concentrations.

\subsection{Flow Data at Gehmkow Gauging Station}

Available daily average discharge data was collected for Gehmkow gauging station (Augraben) for the period from 2009 till 2015. The flow hydrograph below in Figure 6 shows that high flows occur during the winter seasons in comparison to the flows observed during the summer. Flow data was afterwards separated into quick flow and base flow in order to quantify the GW inflow and its role in the overall nitrogen loads in SW. 


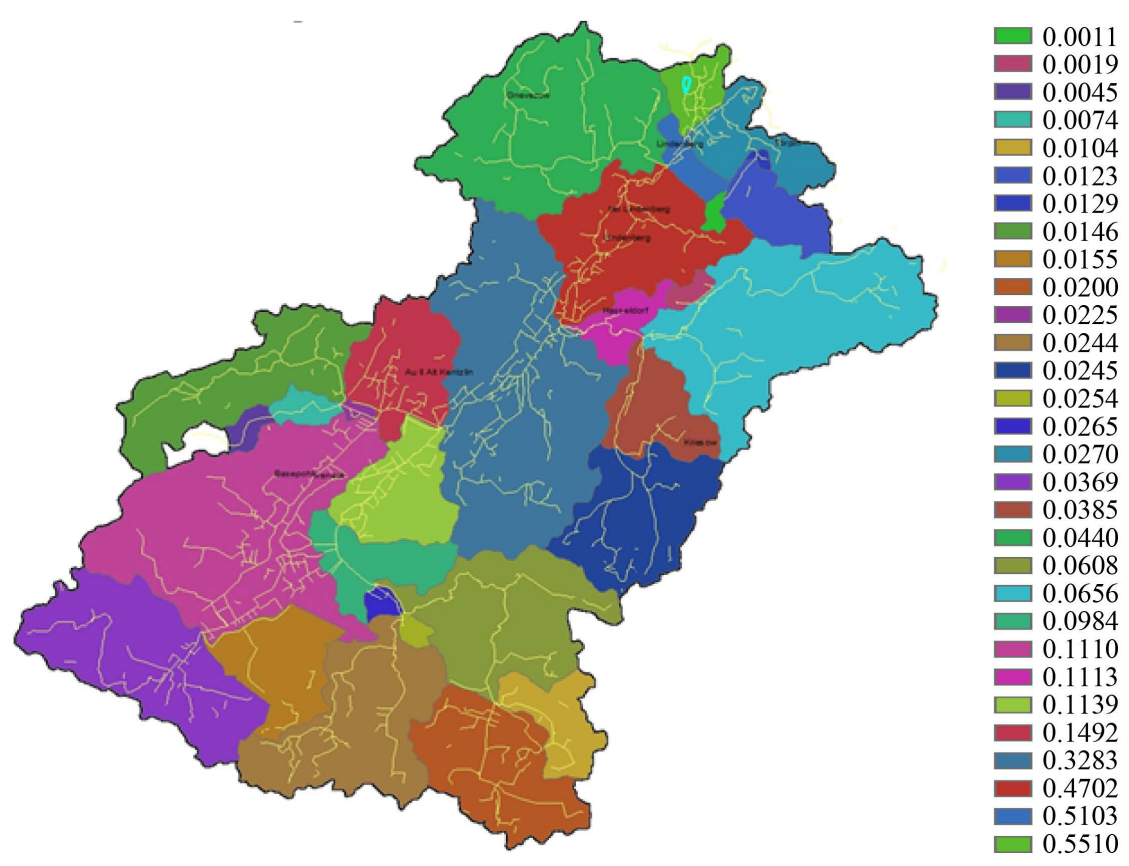

Figure 5. Average available discharges $\left(\mathrm{m}^{3} / \mathrm{sec}\right)$ in the study area from 1980-2010 [31].

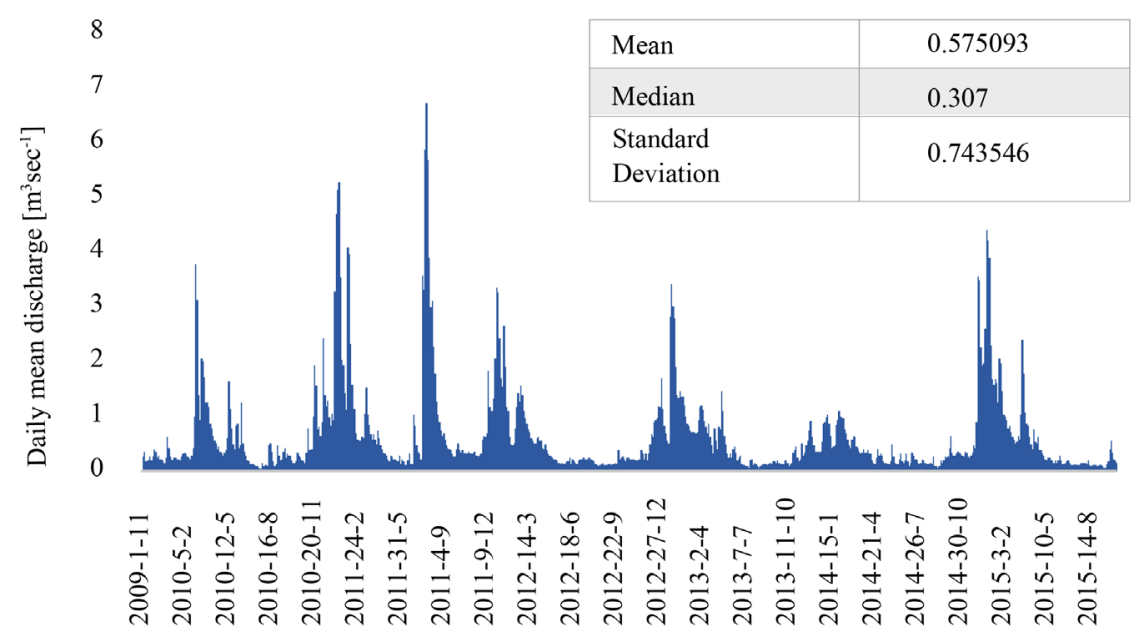

Figure 6. Daily flow hydrograph at Gehmkow gauging station [2009-2015].

\section{Hydrograph Separation with Module BFI+3.0}

Main objective of hydrograph separation is to divide the flow hydrograph into quick flow (a short term response to a rainfall event) and base flow (delayed GW flow). The applied methods can be categorized as 1) graphical methods 2) filtering methods 3) frequency analysis. For hydrograph analysis and its separation different simple and smart tools and programs are available [32] [33]. In this study, the base flow index module BFI+3.0 was applied. BFI+3.0 uses filtering methods to analyze and separate the base flow from total discharge of the catchment.

Continuous hydrograph separation methods involve the division of total flow into two components, quick and the delayed component by using an automated 
time bases separation. Hall [34], defined the delayed portion of flow which originates from GW and other sources as base flow. Base flow time series represents the GW dynamics in a particular catchment. Proportion of base flow from the total flow as an index can represent the ability of a catchment to store and discharge water during the dry periods. Higher value of base flow index shows that the catchment has a stable flow regime and can sustain even during the prolonged dry periods [32].

\subsection{Filtering Methods of Hydrograph Separation}

Filtering methods are the most popular ways of stream flow hydrograph separation into its components as base flow and direct flow. These methods do not have any hydrological and physical basis but they provide a good estimation of base flow. With this principal algorithm it separates base flow as a low frequency signal and direct flow as a high frequency signal. Results of filtering methods are comparable to graphical techniques [35]. Hydrograph separation methods used in this study are described as follows.

\subsubsection{Hydrograph Separation by Lyne \& Hollick}

Following is the algorithm given by Lyne and Hollick [36]

$$
Q_{b(i)}=\alpha Q_{b(i-1)}+\frac{1-\alpha}{2}\left(Q_{T(i)}+Q_{T(i-1)}\right)
$$

where $Q_{b}=$ Base flow, $Q_{T}=$ Total stream flow, $i=$ time step number, $\alpha=$ coefficient (0.925) [37].

\subsubsection{Hydrograph Separation by Nathan and McMohan}

Equation [1] was later modified by Nathan and McMohan [38] as follows

$$
Q_{d(i)}=\alpha Q_{d(i-1)}+\beta(1+\alpha)\left(Q_{T(i)}+Q_{T(i-1)}\right)
$$

where $Q_{d}=$ Direct flow $\left(Q_{d} \geq 0\right)$ for the initial time step, $Q_{T}=$ Total stream flow, $\alpha=$ coefficient (0.925) [37], $\beta=$ coefficient (0.5) [39].

By inserting the values of $\alpha$ and $\beta$ in Equation (2)

$$
Q_{d(i)}=0.925 Q_{d(i-1)}+0.9625\left(Q_{T(i)}+Q_{T(i-1)}\right)
$$

\subsubsection{Hydrograph Separation by Chapman}

Hydrograph separation techniques known as Chapman method was used and is as follows

$$
Q_{d(i)}=\frac{3 \alpha-1}{3-\alpha} Q_{d(i-1)}+\frac{2}{3-\alpha}\left(Q_{T(i)}+Q_{T(i-1)}\right)
$$

where $\alpha=$ coefficient $(0.925)$ [37].

\subsection{GW Inflow in Gehmkow Augraben by Hydraulic Gradient Method/ Darcy's Law}

In parallel, flow through an unconfined aquifer to the SW system was estimated 
by using the Darcy Law. Its application requires the assumption of the following conditions 1) Flow velocity is proportional to the tangent of the hydraulic gradient instead of sine. 2) Flow is considered horizontal and uniform throughout the vertical section. For unidirectional flow, specific discharge is given below

$$
q=-k h \frac{\mathrm{d} h}{\mathrm{~d} x}
$$

where $k=$ hydraulic conductivity, $h=$ water table height above the reference point and $x=$ direction of flow. Figure 7 shows the GW flow to the stream in an unconfined aquifer [25].

On the basis of GW table fluctuations based on the logger data for the period from 2010-2015 provided by LUNG-MV at six boreholes in the study area, Darcy Law was applied and average GW velocities were calculated in all three zones A, B, C and D, are $0.35 \mathrm{~m} /$ day, $0.4 \mathrm{~m} /$ day and 0.057 and $0.04 \mathrm{~m} / \mathrm{d}$ respectively. Only upper aquifer (unconfined aquifer) up to a depth of $5 \mathrm{~m}$ from ground surface was considered to be contributing in the Augraben based on the geological data of boreholes logs also provided by LUNG-MV.

\section{Data Processing}

Comparison of SW and GW quality data obtained from monitoring locations in a lowland artificially drained catchment was used to get an insight to the surface and GW interactions. GW quality concentrations for all the available stations were analyzed for $\mathrm{NO}_{3}-\mathrm{N}, \mathrm{NO}_{2}-\mathrm{N}$ and $\mathrm{NH}_{4}-\mathrm{N}$ concentrations and concentration trends have been established. Due to the lack of permanent monitoring locations GW concentrations was calculated in the catchment area on the basis of average concentrations for the spatial extent of homogeneous areas within the catchment. SW quality and discharge data was analyzed at the gauge station installed near Gehmkow.

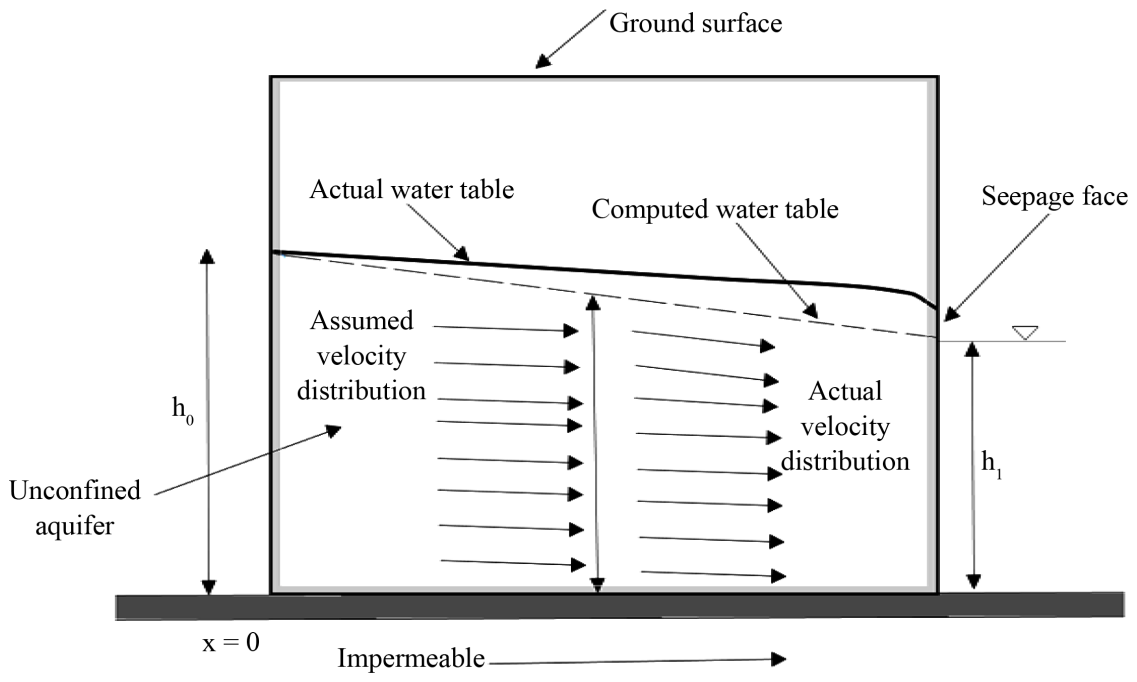

Figure 7. Schematic diagram of GW contribution to the streams in an unconfined aquifer [25]. 


\section{Results}

\subsection{Hydrograph Separation and Role of Drainage}

\section{Hydrograph Separation}

Hydrograph separation was carried out with different mentioned methods and found that CAM estimates the base flow 50\% - 60\% lower than the other methods throughout the considered time period with least value of standard deviation. In case of LMM, N\&M, L\&H, and FIM these methods calculated that around $70 \%-80 \%$ flow in Augraben is the sum of base flow and interflow. In contrast, the calculated GW flow applying Darcy's law was with $6 \%-8 \%$ significantly lower, throughout the whole investigated period.

\section{Drainage Estimation}

This difference between Darcy law and other empirical base flow estimation methods can be explained with delayed interflow from drainage. As in BFI+3.0 all the defined methods do not explicitly consider interflow and drainage effects, the derived base flow may interpreted as the sum of interflow and GW flow, depending on the parametrization and the actual interflow characteristics of the regarded system. The approach, using the Darcy equation is based on the GW and river water levels and can therefore just quantify GW infiltration. So the difference between both approaches, can be interpreted as estimate for interflow, mainly caused by the extensive drainage systems in the catchment. The fairly constant value of base flow by Darcy law is due to very flat GW levels in Gehmkow catchment and water levels in the Augraben as shown in Figure 8. Over all analysis showed that local minimum method overestimates the base flow during high flows, while Nathan and McMohan method remained stable during high and low flows. Local Minimum method, Nathan and McMohan, and Lyne and Hollick method showed similar amount of base flow percentage from total stream flow, while Chapman logarithm yields a rather low base flow. Figure 9 shows the percentages of base flow from the total flow. By taking into consideration the difference, drainage and interflow was estimated to contribute $50 \%$ of the total flow in the Augraben.

\subsection{SW Quality}

\subsubsection{Nitrogen Loads and Concentration during Vegetation and Non-Vegetation Periods}

Vegetation period in northeast Germany was considered on average from April till October every year [40]. A high nitrate concentration was observed during

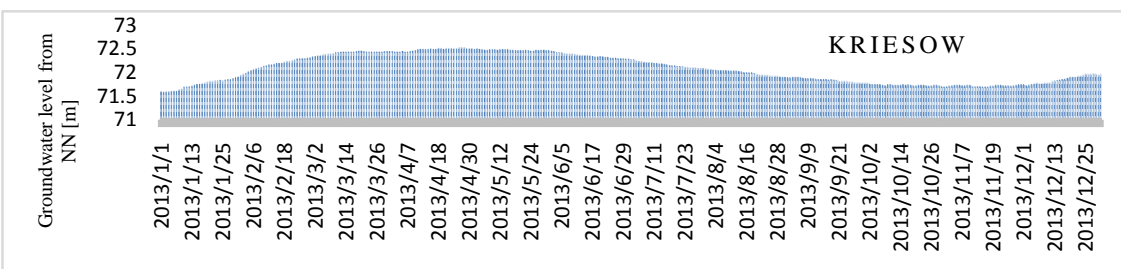

Figure 8. GW levels from normal reference point NN at Kriesow in 2013. 


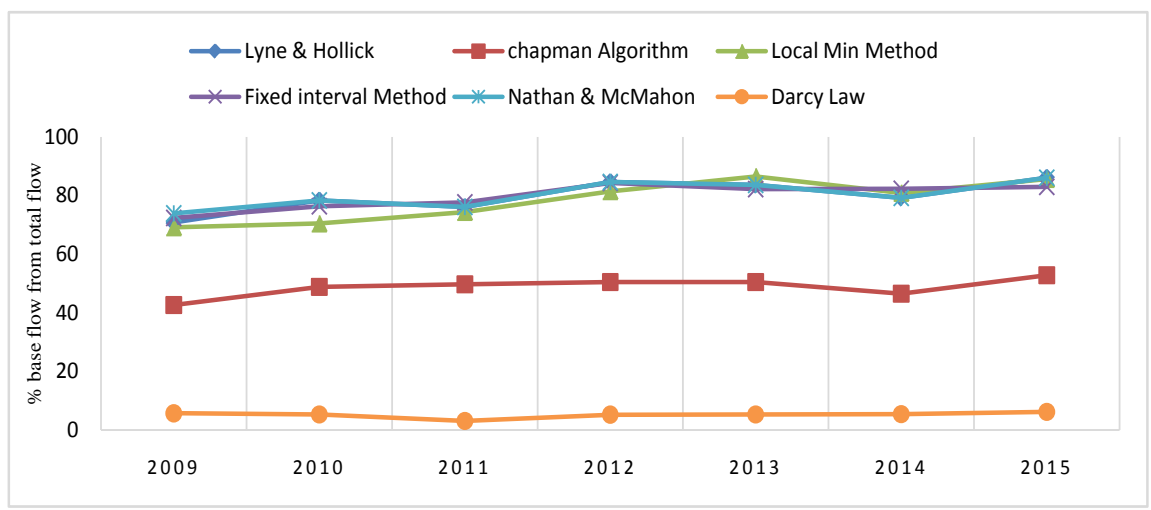

Figure 9. Comparison of $\%$ of base flow separated from total flow by different methods.

the non-vegetation periods between November and February as shown in Figure 10. It can be explained that during non-vegetation period there are no plants uptake of nitrogen compounds from the soil, and due to lower evaporation and transpiration rates, small precipitation rates can result in higher leaching of nutrients than in summer. Moreover, with higher base flows in winter seasons results in higher contribution of GW in total SW nitrogen loads. Figure 10 shows the GW levels throughout the year 2013 at Kriesow. Fertilization rates and their application times also plays an important role. As the applied fertilizers at the harvesting times will be available for leaching during the winter season.

\subsection{Role of GW in Surface Nitrate Loads}

GW quality data was collected and analyzed on three available GW quality monitoring stations Törpin situated in residential area, while Kriesow and Au Alt 11 Kentzlin in agriculture area. Figure 11 shows observed increased and seasonally changing concentrations of ammonia at the GW quality monitoring point in Kriesow, with higher concentrations in summer than in winter. On the other two GW quality monitoring stations in the study area, named as Törpin and Au ll Kentzlin, ammonia is very low and stable during the period between 2011 till 2014. As ammonia is an indicator for the application of animal manure in the agricultural areas. Since the application of liquid manure is by law limited to the vegetation period March to October, the data reflect well the typical agricultural practice. In case of $\mathrm{NO}_{3}-\mathrm{N}$ high concentrations were observed at $\mathrm{Au}$ ll Alt Kentzlin while in case of other two stations it was relatively very low. $\mathrm{NO}_{2}-\mathrm{N}$ shown in Figure 12 showed a gradual decrease except in the year 2013 were all three stations showed a higher concentration.

As shown in Figure 11 at Au II Alt Kentzlin located in zone D, GW quality monitoring station concentrations are more than twice the permissible limits and also contribute maximum nitrate nitrogen load in the Augraben.

In case of Kriesow as shown in Figure 13, overall situation is not good as WHO [41] [42] does recognize odour effects at a concentration of ammonium nitrogen at $1.5 \mathrm{mg} / \mathrm{L}$ and taste effects at $35 \mathrm{mg} / \mathrm{L}$. Ammonium nitrogen can 


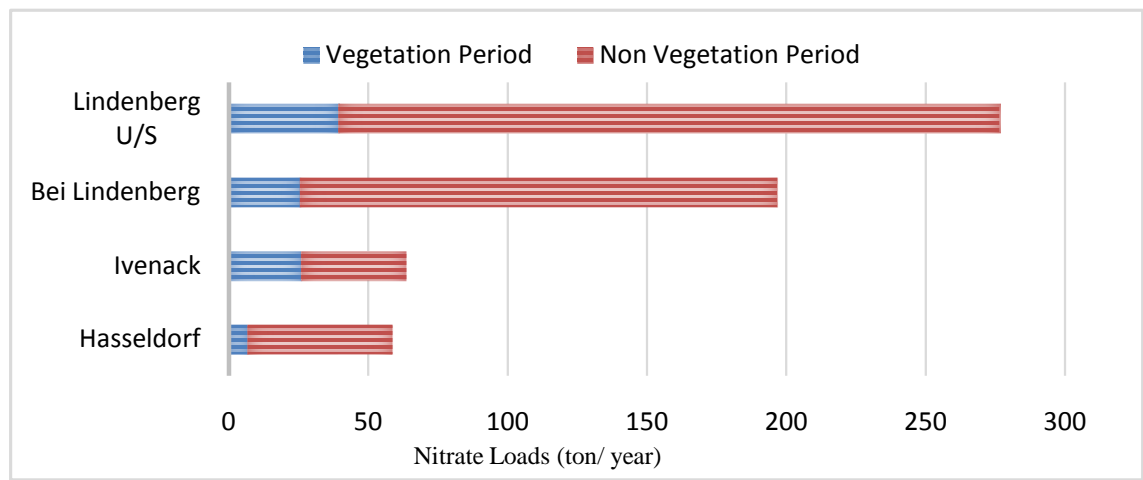

Figure 10. Calculated Nitrate loads at all the available SW quality stations during vegetation and non-vegetation period.
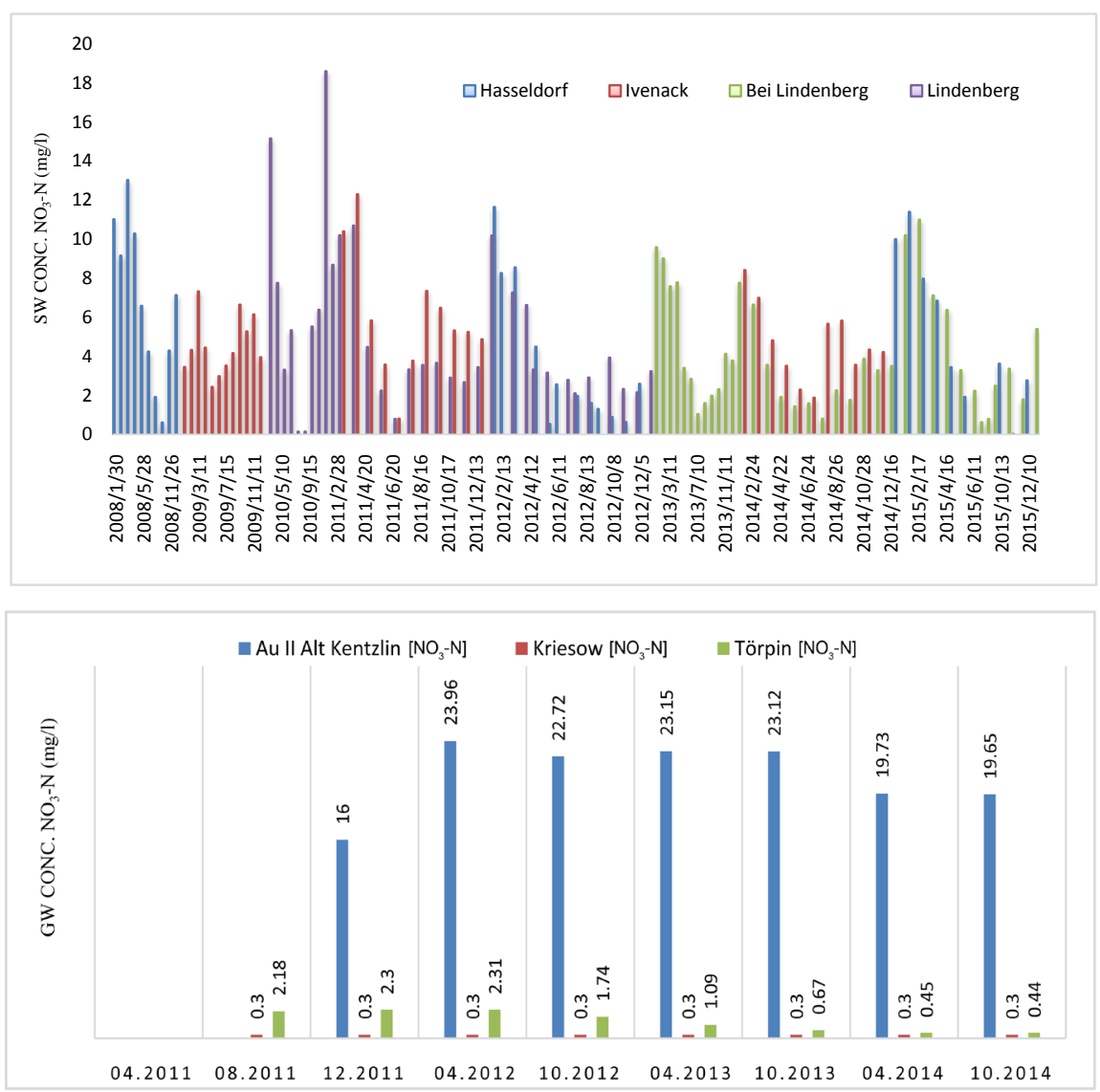

Figure 11. Measured Nitrate nitrogen in SW (up) and GW (down) concentrations at quality monitoring stations in Gehmkow.

change into free ammonia which is toxic for fish and aquatic life based on $\mathrm{pH}$ and temperature and ammonia is toxic to fish and other forms of aquatic life in very low concentration. Accordingly, the German order for surface fresh water systems [43] defines a target value for $\mathrm{NH}_{4}-\mathrm{N}$ of $0.04 \mathrm{mg} / \mathrm{l}$. GW loads of each zone were calculated using Darcy's law since, no flow measurements were available at the respective outlets. A higher SW nitrate loads were observed in Zone 


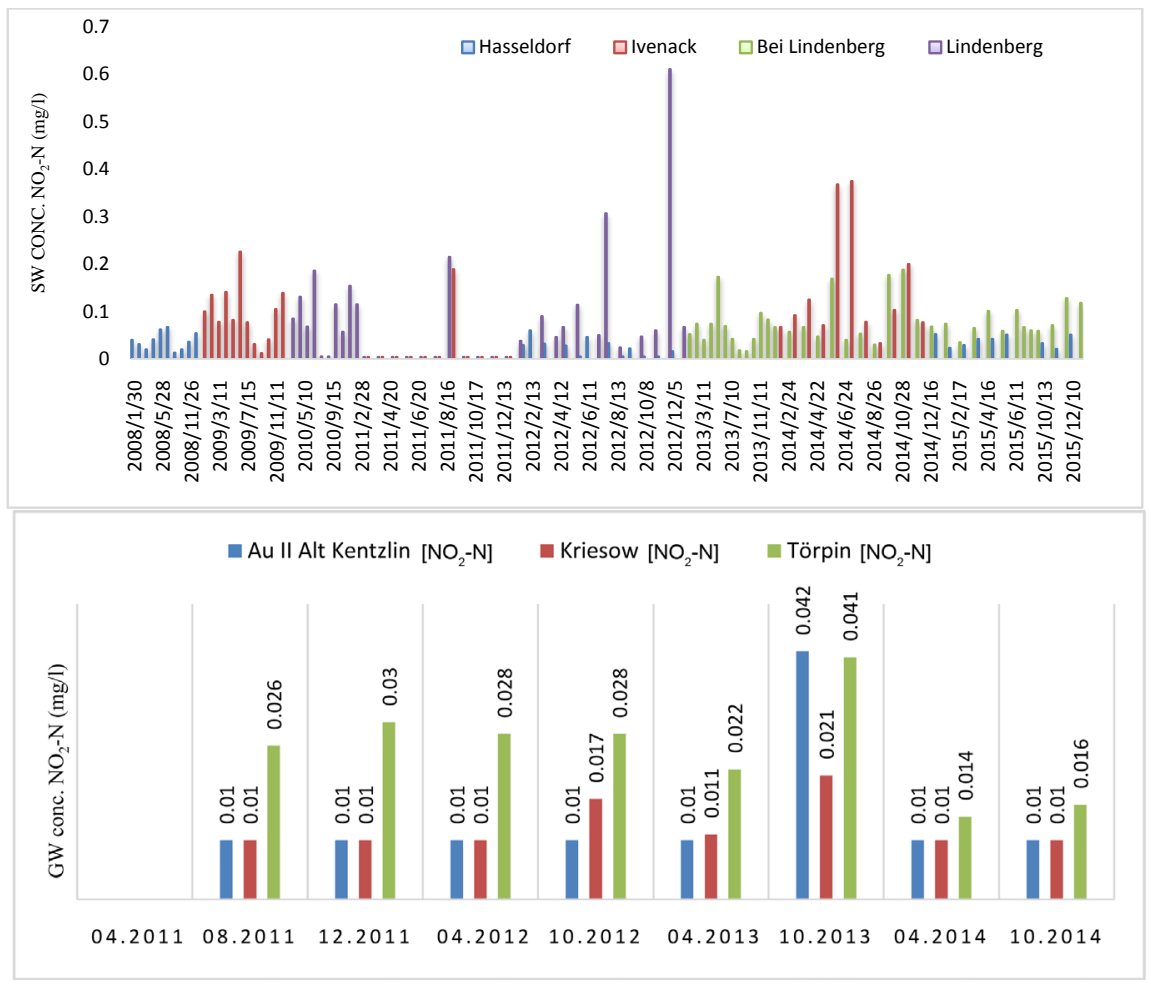

Figure 12. Measured nitrite nitrogen in GW (down) and SW (up) concentrations at quality monitoring stations in Gehmkow.

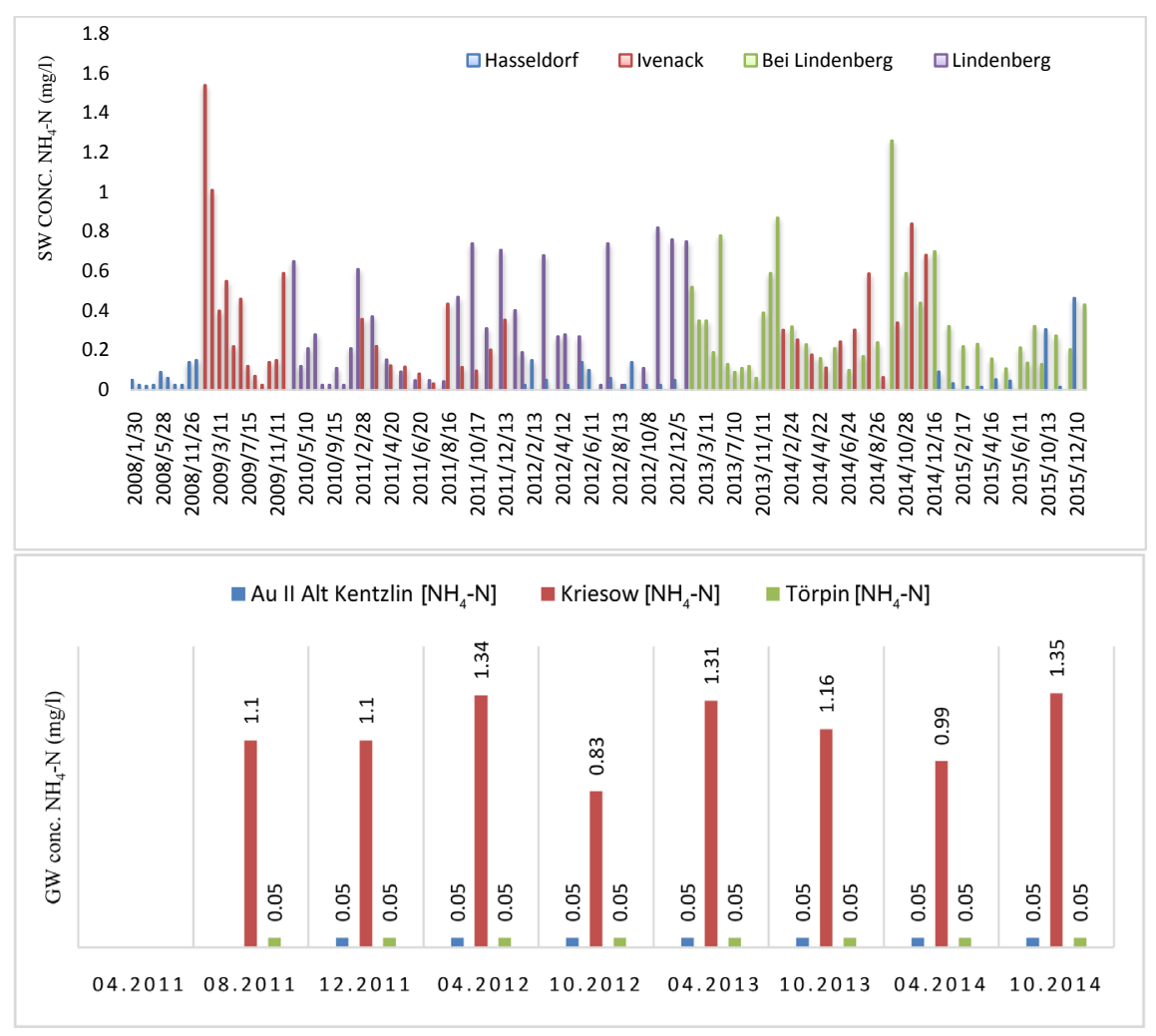

Figure 13. Measured ammonium nitrogen in GW (down) and SW (up) concentrations at quality monitoring stations in Gehmkow. 
D, while zone A and B showed on average lower values of nitrate loads as it can be correlated with GW quality as in case of GW loads zone D showed higher loads in comparison to other zones as shown in Figure 14.

\subsection{Overall SW Quality in Gehmkow Catchment}

Figure 15 shows the total daily average discharge and base flow and $\mathrm{NO}_{3}-\mathrm{N}$ concentrations records at Bei Lindenberg from 2011 to 2015 of Gehmkow Augraben catchment $\left(89.9 \mathrm{~km}^{2}\right.$, location in Figure 1). Discharge data shows a strong correlation between rainfall and river water discharge and high concentrations were observed after periods of rainfalls. Quick drainage of the catchment is due to the presence of artificial drainage network in the area. GIS was used to identify the critical GW pollutant areas on the basis of measured concentrations in the GW. A buffer of 200 (inner circle) and 500 meter (outer circle) was applied shown in Figure 16 to shown the core areas with higher nitrate nitrogen concentrations. GW loads, calculated from estimated base flow calculations from different base flow separation methods and measured GW concentrations resulted that the GW contributes for around $25-45$ percent of the total loads in Augraben while the remaining 55\% - 75\% is probably through the other sources such as drainage system and overland flow and atmospheric deposition. This study also showed that management and monitoring of GW and SW should be done in high temporal and spatial resolution.

\section{Conclusion}

On the basis of analysis of data collected from monitoring programs, it indicates

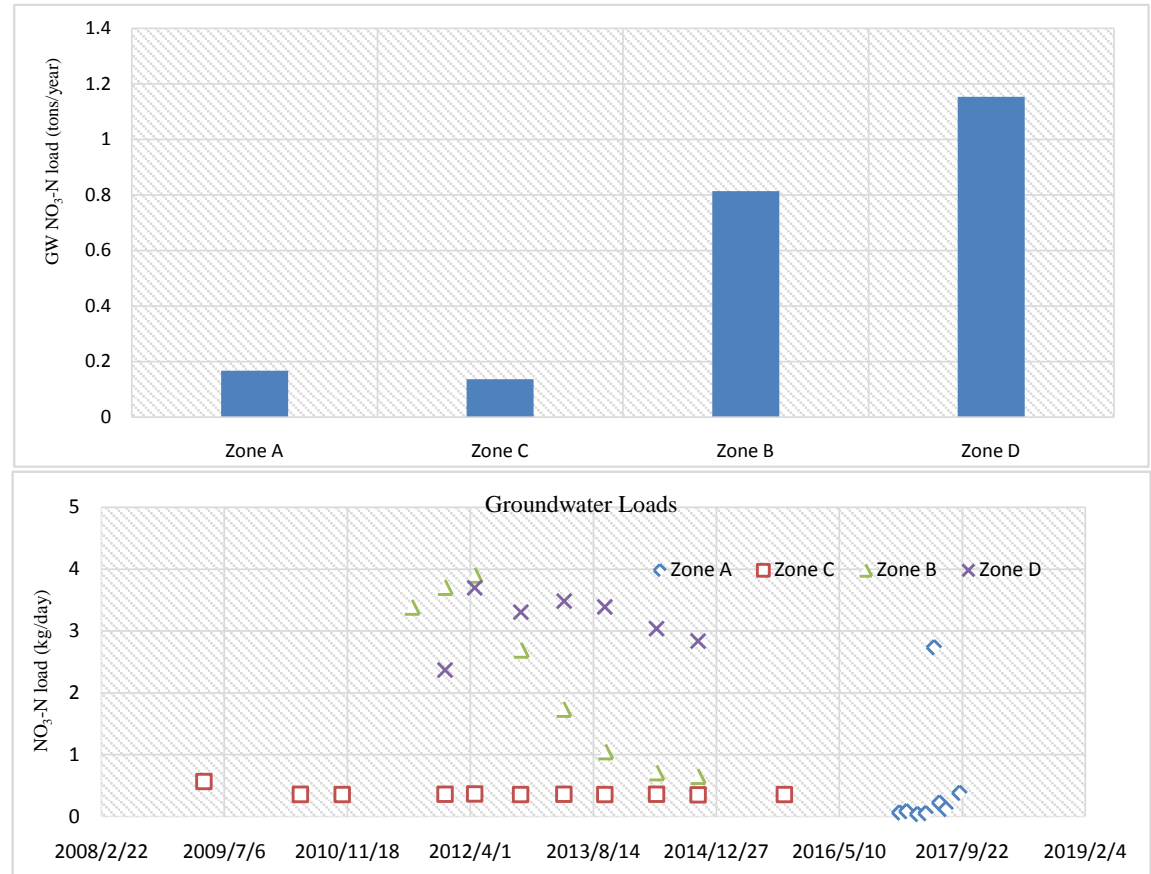

Figure 14. GW loads (down) and their shares (up) in zone A, B, C and D in study area. 


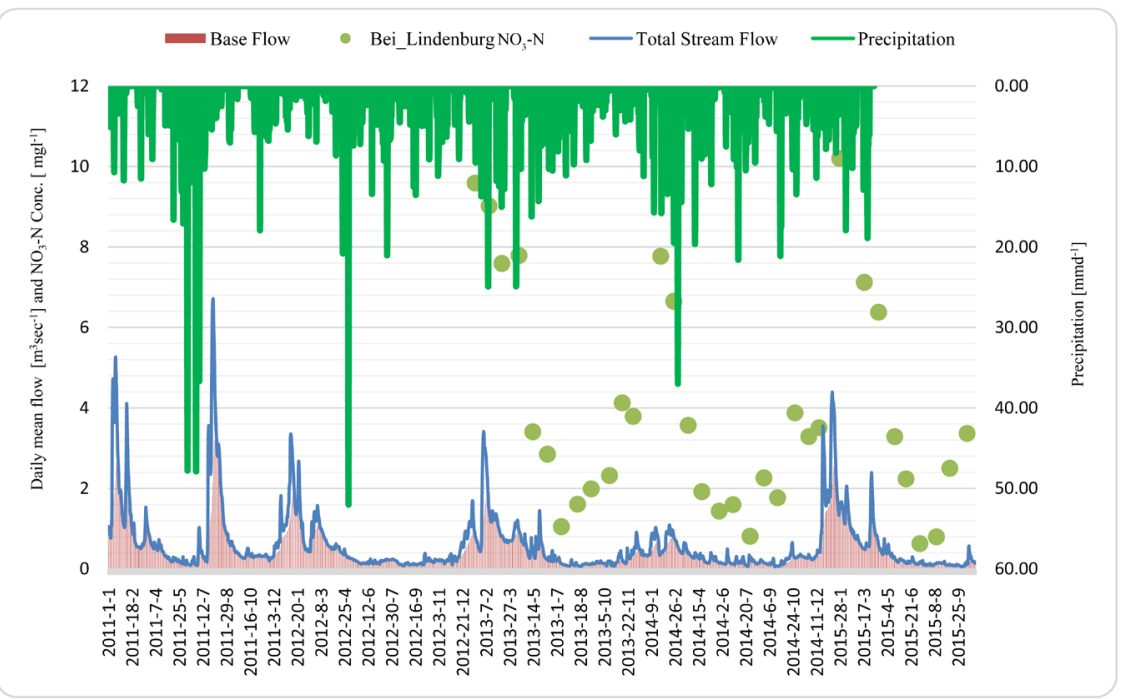

Figure 15. Overall trend of SW concentration and flow in Gehmkow catchment".

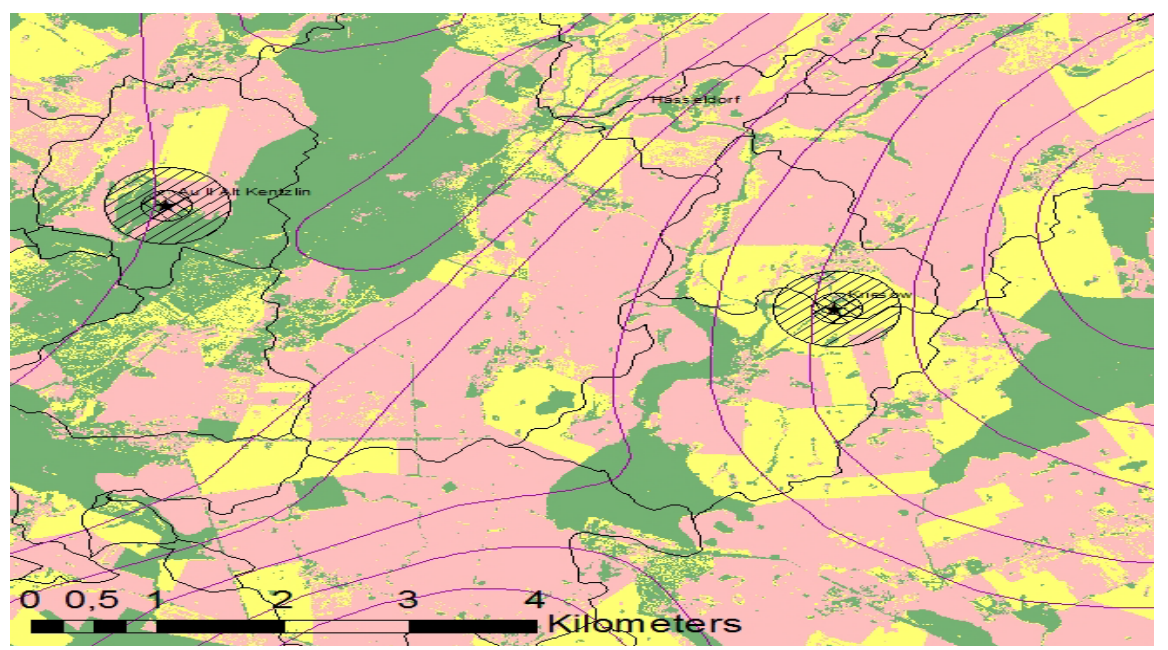

Figure 16. Two hundred and five-hundred-meter buffer zones with nitrate contaminated GWs areas from the Gehmkow Augraben area (green = forest), (pink = arable land), (yellow $=$ crop land).

that GW is one of the dominant contributors to SW contamination in Gehmkow catchment. Test catchment analysis found a strong relationship between SW and GW quality. This means that GW improvement will result in improved standards of SW quality. Different other methods like flow difference method, longitudinal chemistry method (tracer method), and chemical hydrograph separation method should also be considered with gradient flow method and flow hydrograph separation method as these are the simplest ways to quantify the GW role in total nitrogen loads in SW by just using the available monitoring data. In this study, only the upper unconfined aquifer has been considered responsible as a source of base flow, it is possible that in some zones lower aquifers (confined aquifer) are responsible for base flow in the Augraben. For a better local resolution and process understanding, it would be extremely helpful to perform flow monitoring 
at the outlets of drainage channels small channels entering into the Augraben. It is also advisable to collect the GW concentration data in higher resolution than on seasonal basis. This way the correlation between land use and GW concentrations could be described by combining the data analysis and simple flow equations more reliably.

Regarding the EU nitrate directive and EU WFD, the nitrate concentration in GW are just within the limits. But the elevated GW concentration of Nitrate deteriorates directly the SW quality. The method applied here can serve for a rough quantification of this impact.

\section{Acknowledgements}

We would like to thank Dr. Clemens Engelke (State Agency for Environment, Nature Conservation and Geology, Mecklenburg-Vorpommern, Germany), my colleague Mr. Wolfgang Klehr (Faculty of agriculture and environmental sciences, Universität Rostock, Germany) and Ms Ines Staeglich (Staatliche Ämter für Landwirtschaft und Umwelt) for their kind support. This study was performed within a DAAD PhD grant in collaboration with the research project Bootmonitoring in the BMBF program REWAM (FKZ: 033W039A-F).

\section{Software Availability}

BFI+3.0 can be downloaded from the following link and it is open to use. https://hydrooffice.org/Downloads?Items=Software

\section{Conflicts of Interest}

The authors declare no conflict of interest.

\section{References}

[1] Novotny, V. and Chesters, G. (1981) Handbook of Nonpoint Pollution: Sources and Management. Van Nostrand-Reinhold, New York.

[2] Ritter, W.F. and Shirmohammadi, A. (2001) Agricultural Nonpoint Source Pollution. Lewis, Boca Raton, London, New York, Washington DC.

[3] Heathwaite, L., Sharpley, A. and Gburek, W. (2000) A Conceptual Approach for Integrating Phosphorus and Nitrogen Management at Watershed Scales. Journal of Environmental Quality, 29, 158-166. https://doi.org/10.2134/jeq2000.00472425002900010020x

[4] Spalding, R.F. and Exner, M.E. (1993) Occurrence of Nitrate in Groundwater-A Review. Journal of Environmental Quality, 22, 392-402. https://doi.org/10.2134/jeq1993.00472425002200030002x

[5] Campling, P., Terres, J.M., Vande Walle, S., Van Orshoven, J. and Crouzet, P. (2005) Estimation of Nitrogen Balances from Agriculture for EU-15: Specialisation of Estimates to River Basins using the CORINE Land Cover. Physics and Chemistry of the Earth, 30, 25e34.

[6] Nitratbericht (2016) Gemeinsamer Bericht der Bundesministerien für Umwelt, Naturschutz, Bau und Reaktorsicherheit sowie für Ernährung und Landwirtschaft. 
[7] Randall, D.J. and Tsui, T.K.N. (2002) Ammonia Toxicity in Fish. Marine Pollution Bulletin, 45, 17-23. https://doi.org/10.1016/S0025-326X(02)00227-8

[8] Haralambous, A., Maliou, E. and Malamis, M. (1992) The Use of Zeolite for Ammonium Uptake. Water Science \& Technology, 25, Article ID: 139145.

[9] Ip, Y.K., Chew, S.F. and Randall, D.J. (2001) Ammonia Toxicity, Tolerance, and Excretion. Fish Physiology, 20, 109-148. https://doi.org/10.1016/S1546-5098(01)20005-3

[10] Van der Molen, D.T., Breeuwsma, A. and Boers, P.C.M. (1998) Agricultural Nutrient Losses to Surface Water in the Netherlands: Impact, Strategies, and Perspectives. Journal of Environmental Quality, 27, $4 \mathrm{e} 11$.

[11] Oenema, O. and Roest, C.W.J. (1998) Nitrogen and Phosphorus Losses from Agriculture into Surface Waters; The Effects of Policies and Measures in the Netherlands. Water Science and Technology, 37, $19 \mathrm{e} 30$.

[12] Oenema, O., Van Liere, L. and Schoumans, O. (2005) Effects of Lowering Nitrogen and Phosphorus Surpluses in Agriculture on the Quality of Groundwater and Surface Water in the Netherlands. Journal of Hydrology, 304, 289e301.

[13] Addiscott, T.M. and Wagenet, R.J. (1985) Concepts of Solute Leaching in Soils: A Review of Modelling Approaches. Journal of Soil Science, 36, 411-424. https://doi.org/10.1111/j.1365-2389.1985.tb00347.x

[14] HELCOM (2010) Ecosystem Health of the Baltic Sea-HELCOM Initial Holistic Assessment. Baltic Sea Environment Proceedings No. 122, 63 p.

[15] HELCOM (2007) Baltic Sea Action Plan. HELCOM Ministerial Meeting, Krakow, 15 November 2007, 101.

[16] HELCOM (2013) Taking Further Action to Implement the Baltic Sea Action Plan-Reaching Good Environmental Status for a Healthy Baltic Sea. Copenhagen, 19.

[17] Updated Fifth Baltic Sea Pollution Load Compilation (PLC-5.5). http://www.helcom.fi/Lists/Publications/BSEP145_Lowres.pdf

[18] Saaltink, R., van der Velde Ype Dekker, S.C., Lyon, S.W. and Dahlke, H.E. (2014) Societal: Land Cover and Climatic Controls on River Nutrient Flows into the Baltic Sea. Journal of Hydrology: Regional Studies, 1, 44-56.

[19] Hinsby, K., Markager, S., Kronvang, B., Windolf, J., Sonnenborg, T.O. and Thorling, L. (2012) Threshold Values and Management Options for Nutrients in a Catchment of a Temperate Estuary with Poor Ecological Status. Hydrology and Earth System Sciences, 16, 2663-2683. https://doi.org/10.5194/hess-16-2663-2012

[20] Wendland, F., Keller, L., Kuhr, P., Kunkel, R. and Tetzlaff, B. (2015) Regional Differenzierte Quantifizierung der Nährstoffeinträge in das Grundwasser und in die Oberflächengewässer Mecklenburg-Vorpommerns unter Anwendung der Modellkombination Growadenuz-Weku-MEPhos, Endbericht, Herausgeber: LUNG Güstrow.

[21] Brook Zarnow gauging station Zarnow basin, Germany. http://ne-friend.bafg.de/servlet/is/17796/Zarnow.pdf

[22] Koch, F. (2014) Diffuse Nährstoffbelastungen in Oberflächengewässern und im Grundwasser, 19. Gewässersymposium, 19.11.2014 Güstrow.

[23] Rostock. Meeresbiolog. Beitr (2004) Nährstoffausträge in die Ostsee aus diffusen Quellen Mecklenburg-Vorpommerns und Schleswig-Holsteins Nutrient emissions from diffuse sources of Mecklenburg-West Pomerania and Schleswig-Holstein to the Baltic Sea.

[24] McLay, C.D.A., Dragten, R., Sparling, G. and Selvarajah, N. (2001) Predicting Groundwater Nitrate Concentrations in a Region of Mixed Agricultural Land Use: 
A Comparison of Three Approaches. Environmental Pollution, 115, 191-204. https://doi.org/10.1016/S0269-7491(01)00111-7

[25] Methods for Estimating Groundwater Discharge to Streams-Summary of Field Trials.

http://www.environment.gov.au\%2Fsystem\%2ffiles\%2Fpages\%2Ff4c0c901-66bc-46 ba-94cb-056dfb54b69d\%2Ffiles\%2Fmethods-estimating-groundwater-discharge-str eams.doc\&usg=AFQjCNHYTL-YQN4tMfyks65LLi_pr2-qjQ

[26] Rapid Eye Science Archive (RESA). http://www.resa.blackbridge.com

[27] Nikkarinen, M., Kauniskangas, E. and Nenonen, K. (1996) Use of Geological and Geochemical Data for the Derivation of Maps for Environmental Planning in Iisalmi, Finland. Applied Geochemistry, 11, 261-270. https://doi.org/10.1016/0883-2927(95)00038-0

[28] Canter, L.W., Knox, R.C. and Fairchild, D.M. (1988) Ground Water Quality Protection. Lewis Publishers, Chelsea, $562 \mathrm{p}$.

[29] Lee, S.H. and Kim, Y.L. (1996) The Management of Groundwater Contamination in Seoul using GIS. Proceedings of Journal of the Korean Society of Groundwater Environment, 40-44.

[30] ESRI (1994) Understanding GIS. ESRI, Inc., Redlands, 2-31.

[31] BIOTA (2012) Überarbeitung und Aktualisierung der Karte der mittleren Abflüsse und mittleren Niedrigwasserabflüsse für Mecklenburg-Vorpommern. biota Institut für ökologische Forschung und Planung GmbH im Auftrag des Landesamtes für Umwelt, Naturschutz und Geologie Mecklenburg-Vorpommern, $97 \mathrm{~S}$.

[32] Tallaksen, L.M. and Van Lanen, H.A. (2004) Hydrological Drought: Processes and Estimation Methods for Streamflow and Groundwater. Vol. 48, Elsevier, Amsterdam.

[33] Sloto, R.A. and Crouse, M.Y. (1996) HYSEP, a Computer Program for Streamflow Hydrograph Separation and Analysis. US Department of the Interior, US Geological Survey.

[34] Hall, F.R. (1968) Base Flow Recessions-A Review. Water Resources Research, 4, 973-983. https://doi.org/10.1029/WR004i005p00973

[35] Arnold, J.G. and Fohrer, N. (2005) SWAT2000: Current Capabilities and Research Opportunities in Applied Watershed Modeling. Hydrological Processes, 19, 563-572. https://doi.org/10.1002/hyp.5611

[36] Lyne, V. and Hollick, M. (1979) Stochastic Time-Variable Rainfall-Runoff Modeling. Institute of Engineers Australia National Conference, 89-93.

[37] Gregor, M. (2010) BFI+ 3.0.

[38] Nathan, R.J. and Mcmahon, T.A. (1990) Evaluation of Automated Techniques for Base Flow and Recession Analyses. Water Resources Research, 26, 1465-1473.

[39] Welderufael, W.A., Le Roux, P.A.L. and Hensley, M. (2009) Quantifying Rainfall Runoff Relationships on the Melkassa Hypo Calcic Regosol Ecotope in Ethiopia. Water SA, 35, 639-648. https://doi.org/10.4314/wsa.v35i5.49189

[40] Growing Season in Germany. https://en.wikipedia.org/wiki/Growing_season

[41] WHO (1985) Guidelines for the Study of Dietary Intake of Chemical Contaminants. World Health Organization, Geneva, WHO Offset Publication No. 87.

[42] WHO (1985) Health Hazards from Nitrate in Drinking-Water. Report, WHO Meeting, Copenhagen, 5-9 March 1984, Environmental Health Series No. 1.

[43] OGewV (2015) Verordnung zum Schutz der Oberflächengewässer. https://www.gesetze-im-internet.de/ogewv_2016/BJNR137310016.html 